\title{
Diet crude protein content and sources for lactating dairy cattle
}

\author{
Hugo Imaizumi ${ }^{1}$; Flávio Augusto Portela Santos ${ }^{2 *}$; Carla Maris Machado Bittar ${ }^{2}$; Paulo \\ Sérgio Correia ${ }^{1}$; Júnio César Martinez ${ }^{1}$ \\ ${ }^{1}$ USP/ESALQ - Programa de Pós-Graduação em Ciência Animal e Pastagens. \\ ${ }^{2}$ USP/ESALQ - Depto. de Zootecnia, C.P. 9 - 13418-900 - Piracicaba, SP - Brasil. \\ *Corresponding author <fapsanto@esalq.usp.br>
}

\begin{abstract}
Feeding extra protein as an attempt to increase amino acid flux to the intestine may increase lactational performance of dairy cattle. The objective of this study was to compare lactating dairy cow diets containing $16 \%$ crude protein (CP), adequate in rumen degradable protein (RDP) and metabolizable protein (MP) according to NRC (2001), with diets containing 17.5\% CP. Forty-two Holstein cows (27 primiparous and 15 multiparous, with 172 days in milk) were used in a $3 \times 3$ Latin Square design with 14 replicates. Control diet consisted of $16 \% \mathrm{CP}$, adequate in RDP and MP . Crude protein content of diets was increased to $17.5 \%$ by feeding extra soybean meal and cottonseed meal (SBCS-17.5) to increase diet MP, or extra urea (U-17.5) to increase diet RDP. The experiment was carried out during 60 days with three periods. Animals were groupfed a total mixed ration and milked twice a day. Dry matter intake was higher for the U-17.5 diet $(p<0.15)$ than for the control diet. Milk $(p<0.01)$ and $3.5 \%$ fat corrected milk (FCM-3.5\%) $(p<0.05)$ yields were increased by extra soybean and cottonseed meal (SBCS-17.5) but not by extra urea (U-17.5). Milk fat content and yield were not affected by treatments $(p>0.05)$. Milk protein content decreased $(p<0.01)$ by feeding extra urea (U-17.5). However, higher $(p<0.01)$ protein yields were observed for the SBCS-17.5 treatment. For cows milking around $29 \mathrm{~kg} \mathrm{~d}^{-1}$, increasing diet CP content to $17.5 \%$, by feeding extra soybean and cottonseed meal, beyond recommendations for RDP and MP, increased yields of milk, yields of $3.5 \%$ fat corrected milk and yields of milk protein.
\end{abstract}

Key words: cottonseed meal, metabolizable protein, protein sources, rumen degradable protein, soybean meal

\section{Quantidades e formas de proteína dietética para vacas em lactação}

RESUMO: O fornecimento de dietas com maior teor de proteína para aumentar o fluxo de aminoácidos para o intestino pode aumentar o desempenho lactacional. Compararam-se dietas para vacas em lactação contendo $16 \%$ de proteína bruta $(\mathrm{PB})$, adequada em proteína degradável no rúmen (PDR) e proteína metabolizável (PM) (NRC, 2001) com dietas com maiores teores de PB (17,5\%). Quarenta e duas vacas (27 primíparas e 15 multíparas, com 172 dias em lactação) foram utilizadas em um delineamento do tipo Quadrado Latino $3 \times 3$, com 14 repetições. A dieta controle continha 16\% de PB e era adequada em PDR e PM de acordo com o NRC (2001). O teor de PB das dietas foi aumentado para 17,5\% através do aumento no fornecimento de farelo de soja e de algodão (SBCS-17,5) para aumentar a PM, ou uréia (U-17,5) para aumentar a PDR. O experimento teve duração de 60 dias com três subperíodos. Os animais foram alimentados em grupo com ração completa e ordenhados duas vezes ao dia. O consumo de matéria seca foi maior para a dieta U-17,5 $(p<0,15)$ do que para a dieta controle. A produção de leite $(p<0,01)$ e de leite corrigido para gordura 3,5\% (LCG-3,5\%) $(p<0,05)$ foram aumentadas com o maior fornecimento de farelo de soja e de algodão (SBCS-17,5) mas não pelo maior fornecimento de uréia $(U-17,5)$. O teor e a produção de gordura do leite não foram afetados $(p>0,05)$ pelos tratamentos. O teor de proteína foi reduzido $(p<0,01)$ pelo maior fornecimento de uréia $(\mathrm{U}-17,5)$; enquanto maior produção de proteína do leite $(p<0,01)$ foi observada para o tratamento SBCS-17,5. Para vacas produzindo em torno de $29 \mathrm{~kg} \mathrm{~d}^{-1}$, aumentar o teor de $\mathrm{PB}$ para 17,5\%, por meio do maior fornecimento de farelo de soja e de algodão, acima das recomendações do NRC (2001) para PDR e PM, resultou em aumentos na produção de leite, leite corrigido para gordura e de proteína do leite.

Palavras-chave: farelo de algodão, farelo de soja, fontes de proteína, proteína degradável no rúmen, proteína metabolizável

\section{Introduction}

Optimizing the balance between microbial protein synthesis and protein degradation in the rumen of lactating cows has the potential to optimize lactational performance and reduce nitrogen excretion to the environment. New systems and models of diet formulation have been developed and include complex calculations aimed to estimate protein synthesis and degradation in the ru- men for feeding adequate amounts of rumen degradable protein $(\mathrm{RDP})$ to microbes and metabolizable protein (MP) to the dairy cow (AFRC, 1992; CNCPS, 1992; NRC, 1985; NRC, 1989; NRC, 2001). A further improvement in diet formulation is to balance the metabolizable protein for essential amino acids, primarily lysine and methionine (NRC, 2001).

Extra dietary protein can be fed to reduce the possibility of an amino acid deficiency at the intestinal level, 
which otherwise may result in lower lactational performance (Broderick, 2003; Colin-Schoellen et al., 2000; Hof et al., 1997; Moorby et al., 1996; Reynal and Broderick, 2003). However, excessive protein feeding increases feed costs, decreases efficiency of nutrient utilization (Tamminga, 1992), and may reduce cow fertility (Canfield et al., 1990; Rajala-Schultz et al., 2001).

According to the multivariate regression analysis (NRC, 2001) milk production increased $0.75 \mathrm{~kg} \mathrm{~d}^{-1}$ when dietary crude protein (CP) was increased from 15 to $16 \%$ and $0.35 \mathrm{~kg} \mathrm{~d}^{-1}$ when CP was increased from 19 to $20 \%$. Maximum milk yield was achieved at 23\% CP in the diet. Similar results were reported by Ipharraguerre and Clark (2005a) using a larger data set (112 studies published from 1981-2003) and different methodologies. They estimated increases in milk yield of 0.94 and 0.42 $\mathrm{kg} \mathrm{d}^{-1}$ when dietary CP was increased from 15 to 16 and 19 to $20 \%$, respectively. Maximum milk yield was achieved at $22.8 \% \mathrm{CP}$.

We reviewed 13 studies regarding amounts of protein in diets for lactating dairy cows from 2005 through 2009 (Ipharraguerre and Clark, 2005b; Reynal and Broderick, 2005; Groff and Wu, 2005; Olmos Colmeneiro and Broderick, 2006a,b; Kalscheur et al., 2006; Wang et al, 2007; Cabrita et al., 2007; Cyriac et al., 2008; Law et al, 2009). Milk yield was consistently increased as dietary CP below $15 \%$ was increased up to $15-17 \%$. In most of these studies dry matter intake was not affected by dietary CP. In seven of the 13 reviewed studies cows produced from 36.3 to $43.3 \mathrm{~kg}$ of milk per day (Ipharraguerre and Clark, 2005b; Reynal and Broderick, 2005; Groff and Wu, 2005; Olmos Colmeneiro and Broderick, 2006a,b; Cyriac et al., 2008). For these high producing cows, increasing dietary CP from $16.2-17.2 \%$ up to $20 \%$ did not increase milk yield in seven and dry matter intake (DMI) in five of seven studies. Milk protein yield was not affected in six of seven studies, but milk urea nitrogen (MUN) was increased in seven and $\mathrm{N}$ efficiency (milk protein $\mathrm{N}$ as a $\%$ of $\mathrm{N}$ intake) decreased in six studies.

The objective of this study was to evaluate the adequacy of a diet containing $16 \%$ of crude protein, adequate in RDP and MP (NRC, 2001), with diets higher in CP (17.5\%) and containing either higher levels of RDP and MP (extra soybean and cottonseed meal) or higher levels of RDP (extra urea) for mid lactating dairy cows.

\section{Material and Methods}

Forty-two lactating Holstein cows (27 primiparous and 15 multiparous), housed in a free-stall barn, were distributed in three pens of fourteen cows each. Average body weight (BW), milk production and days in milk (DIM) at the beginning of the trial were $535 \pm 70$ $\mathrm{kg}, 29.7 \pm 5.9 \mathrm{~kg}$ and $158 \pm 78$ days and $648 \pm 57 \mathrm{~kg}$, $34.8 \pm 6.0 \mathrm{~kg}$ and $188 \pm 39$ days respectively for primiparous and multiparous cows. All cows received an injection of somatotropin every ten days from the beginning of the study.
The study was carried out to compare three treatments (Table 1): control, SBCS-17.5 and U-17.5. The control treatment, containing $16 \%$ crude protein $(\mathrm{CP})$ on dry matter (DM) basis, was formulated to be adequate (NRC, 2001) in rumen degradable protein (RDP), rumen undegradable protein (RUP), and consequently in metabolizable protein (MP) for primiparous cows weighting $500 \mathrm{~kg} \mathrm{BW}$, consuming $20.5 \mathrm{~kg} \mathrm{DM}$ and producing $33 \mathrm{~kg}$ of milk, at 160 DIM. In the SBCS-17.5 treatment, $\mathrm{CP}$ content was increased from 16 to $17.5 \%$ by the inclusion of extra soybean meal and cottonseed meal, resulting in greater amounts of RDP, RUP, and MP. In the U-17.5 treatment, crude protein content was increased to $17.5 \%$ by the inclusion of extra urea which increased the amount of RDP without changing RUP or MP.

A $3 \times 3$ Latin Square design with 14 replicates was utilized. To maintain homogeneity within each Latin Square, animals were grouped according to milk yields measured during seven days of the pre-experimental period, days in milk (DIM) and parity. All experimental treatments contained nine primiparous and five multiparous cows. The three experimental periods lasted 20 days each one and consisted of ten days for diet adaptation and ten days for data and sample collections.

Cows were milked twice daily (6h00 and 18h00) and individual milk yields recorded on days 13, 15, 17 and 19 of each period, using the MARK5 (De Laval, Tumba, Sweden) equipment. Individual milk samples were collected in a 1:1 ratio for morning and afternoon milkings and analyzed for fat, protein, lactose, and total solids by the infrared Bentley 2000 (Bentley Instruments, Inc., Chaska, MN, USA) and milk urea $\mathrm{N}$ using a ChemSpec 150 (Bentley Instruments, Inc., Chaska, MN, USA).

Feed was offered as a total mixed ration twice a day (6h00 and 17h00) using a mixer wagon and orts were collected and measured daily before morning feeding. Amounts of feed offered to the cows were adjusted to allow refusals equal to $10 \%$ of the offer. Corn silage was sampled weekly and dried at $105^{\circ} \mathrm{C}$ for DM content determination, allowing diet formulation adjustments. For chemical composition analyses, corn silage, cottonseed meal and total mixed ration samples were collected daily during the last 10 days of each period, composited by sub-period, oven dried at $55^{\circ} \mathrm{C}$ for $72 \mathrm{~h}$ (Silva, 1990), ground using a Wiley Mill with a $1 \mathrm{~mm}$ screen and analyzed for DM, ash, ether extract and $\mathrm{CP}$ according to AOAC (1990), neutral detergent fiber (NDF) and acid detergent fiber $(\mathrm{ADF})$ as proposed by Van Soest et al. (1991), adapted for the ANKOM200 methodology (ANKOM200 Fiber Analyzer, ANKOM Technology Corporation, Fairport, NY, USA), and lignin according to Goering and Van Soest (1970). For diet formulations tabular values (NRC, 2001) were used for corn, citrus pulp and soybean meal.

Blood samples from the coccygeal vessels were obtained from the six highest producing cows of each treatment group, $4 \mathrm{~h}$ after morning feeding (around $11 \mathrm{~h} 00-$ 
12h00) of the last day of each collection period. Samples were collected using vaccutainers with potassium oxalate as an anticoagulant. After collection, samples were centrifuged for 20 minutes to $2,000 \times g$ at $4^{\circ} \mathrm{C}$. Plasma samples were stored at $-10^{\circ} \mathrm{C}$ until analyzed for plasma glucose by an auto-analyzer (YSI 2700 Select - Biochemistry analyzer, Yellow Spring, OH, USA) and for plasma urea nitrogen (PUN) by a commercial laboratory using a Sigma N-535 kit (Sigma Chemical Co., St. Louis, MO, USA). Body condition scores were given to all cows at the first and the last day of each period, using the one to five points range according to Wildman et al. (1982).

Data were subjected to statistical analyses using the SAS (1991) GLM procedure. Because cows were group fed, DMI was measured on a pen basis with one pen per treatment during each period. Therefore pen was considered as the experimental unit for statistical analysis of DMI. Cows were considered as the experimental unit for statistical analysis of milk yield and composition, blood parameters and body condition score variation. Data were tested for normal distribution by the UNIVARIATE procedure (SAS, 1991), and values out- side the range of \pm 3 standard deviations were discarded from statistical analysis. For the $\mathrm{F}$ and Tukey tests, a $5 \%$ significance level was considered, except for DMI where a $15 \%$ significance level was considered. All averages were obtained by the least square means method (LSMEANS).

\section{Results and Discussion}

Chemical composition of experimental diets and corn silage are presented in Table 1 and 2 respectively. Data for DMI, milk production and composition, and blood parameters are shown in Table 3. Dry matter intake was affected by treatments $(p<0.15)$. Increasing diet CP by feeding extra urea (U-17.5) increased DMI. Feeding extra soybean and cottonseed meal resulted in non significant numerically higher DMI, compared to the control diet.

Low crude protein diets may result in RDP deficiency and impact negatively on rumen fermentation and microbial synthesis, decreasing metabolizable energy and protein availability for dairy cows. RUP may also be deficient in low crude protein diets, reducing metabo-

Table 1 - Experimental diet composition.

\begin{tabular}{|c|c|c|c|}
\hline & & Treatments $^{1}$ & \\
\hline & Control & SBCS-17.5 & U-17.5 \\
\hline Ingredients (\% DM) & & & \\
\hline Corn silage & 43.84 & 43.83 & 43.84 \\
\hline Soybean meal & 9.74 & 12.91 & 9.89 \\
\hline Cottonseed meal & 9.74 & 12.91 & 9.89 \\
\hline Ground corn & 16.42 & 13.42 & 16.03 \\
\hline Citrus pulp & 16.42 & 13.42 & 16.03 \\
\hline Urea & 0.34 & - & 0.83 \\
\hline Mineral-vitamin $\operatorname{mix}^{2}$ & 2.83 & 2.83 & 2.83 \\
\hline Sodium bicarbonate & 0.68 & 0.68 & 0.68 \\
\hline Chemical composition & & & \\
\hline & - & --- \%DM - & -1---- \\
\hline Crude Protein ${ }^{3}$ & 15.9 & 17.5 & 17.4 \\
\hline Rumen Degradable Protein ${ }^{4}$ & 10.2 & 10.8 & 11.6 \\
\hline Rumen Undegradable Protein ${ }^{4}$ & 5.7 & 6.7 & 5.8 \\
\hline Metabolizable Protein ${ }^{4}$ & 10.8 & 11.8 & 10.8 \\
\hline Ether Extract ${ }^{3}$ & 2.7 & 2.7 & 2.7 \\
\hline Neutral Detergent Fiber ${ }^{3}$ & 30.3 & 30.8 & 30.3 \\
\hline Forage $\mathrm{NDF}^{4}$ & 21.3 & 21.3 & 21.3 \\
\hline Non Fiber Carbohydrate ${ }^{4}$ & 45.6 & 43.7 & 44.3 \\
\hline Total Digestible Nutrients ${ }^{4}$ & 70.2 & 70.0 & 69.8 \\
\hline NE lactation (Mcal kg DM-1-1 & 1.56 & 1.57 & 1.54 \\
\hline
\end{tabular}

${ }^{1}$ Treatments: Control $=16 \%$ CP; SBCS-17.5 $=17.5 \%$ CP, with extra soybean meal and cottonseed meal; U-17.5 = 17.5\% CP, with extra urea. ${ }^{2}$ Composition: $\mathrm{Ca}, 23.24 \% ; \mathrm{P}, 5.50 \% ; \mathrm{K}, 0.02 \% ; \mathrm{Mg}, 3.50 \% ; \mathrm{Cl}, 10.53 \% ; \mathrm{Na}, 7 \%$;, $2.20 \% ; 0.05 \%$ of sodium monensin; and (by kg) $12 \mathrm{mg} \mathrm{Co} ; 450 \mathrm{mg} \mathrm{Cu} ; 40 \mathrm{mg} \mathrm{I} ; 4,327 \mathrm{mg} \mathrm{Fe} ; 1,500 \mathrm{mg} \mathrm{Mn} ; 12 \mathrm{mg} \mathrm{Se} ; 1,800 \mathrm{mg}$ Zn; 130,000 IU vitamin A; 75,000 IU vitamin D; 1,000 IU vitamin E. ${ }^{3}$ Based on TMR chemical analyzes. ${ }^{4}$ Values estimated according to NRC (2001) based on feed analyzes (corn silage and cottonseed meal) and tabular values (corn, citrus pulp and soybean meal); NE lactation = net energy of lactation; $\mathrm{NFC}=$ nonfiber carbohydrates. 
Table 2 - Chemical composition of corn silage and cottonseed meal ${ }^{1}$.

\begin{tabular}{lcccccccc}
\hline Ingredient & DM & CP & EE & Ashes & TDN & ADF & NDF & Lig \\
\hline Corn silage & 28.29 & 7.13 & 2.73 & 4.35 & 65.46 & 29.71 & 48.51 & 3.64 \\
Cottonseed meal & 89.37 & 43.75 & 3.12 & 6.80 & 66.94 & 22.37 & 32.11 & 7.77 \\
\hline
\end{tabular}

${ }^{1} \mathrm{DM}=$ dry matter $\mathrm{CP}=$ crude protein; $\mathrm{EE}=$ ether extract; $\mathrm{TDN}=$ total digestible nutrients; $\mathrm{ADF}=$ acid detergent fiber; NDF $=$ neutral detergent fiber; $\mathrm{Lig}=$ lignin. TDN values were estimated according to NRC (2001).

Table 3 - Dry matter intake, milk production and composition, body condition score change and blood parameters according to treatments.

\begin{tabular}{|c|c|c|c|c|c|}
\hline \multirow{2}{*}{ Variable $^{1}$} & \multicolumn{3}{|c|}{ Treatments ${ }^{2}$} & \multirow{2}{*}{$\mathrm{SEM}^{3}$} & \multirow{2}{*}{$p^{4}$} \\
\hline & Control & SBCS-175 & $\mathrm{U}-17.5$ & & \\
\hline Dry matter intake, $\mathrm{kg} \mathrm{d}^{-1}$ & $20.64^{\mathrm{B}}$ & $21.43^{\mathrm{AB}}$ & $21.77^{\mathrm{A}}$ & 0.23 & $<0.15$ \\
\hline Milk production, $\mathrm{kg} \mathrm{d}^{-1}$ & $28.72^{b}$ & $29.74^{a}$ & $28.13^{\mathrm{b}}$ & 0.21 & $<0.01$ \\
\hline $3.5 \% \mathrm{FCM}, \mathrm{kg} \mathrm{d}^{-1}$ & $27.06^{b}$ & $28.32^{a}$ & $27.31^{\mathrm{ab}}$ & 0.36 & $<0.05$ \\
\hline Milk fat content, $\%$ & 3.16 & 3.24 & 3.29 & 0.05 & NS \\
\hline Milk fat yield, $\mathrm{kg} \mathrm{d}^{-1}$ & 0.90 & 0.95 & 0.92 & 0.02 & NS \\
\hline Milk protein content, \% & $3.09^{a}$ & $3.10^{a}$ & $3.06^{b}$ & 0.01 & $<0.01$ \\
\hline Milk protein yield, $\mathrm{kg} \mathrm{d}^{-1}$ & $0.88^{b}$ & $0.92^{\mathrm{a}}$ & $0.86^{b}$ & 0.01 & $<0.01$ \\
\hline Lactose content, \% & 4.66 & 4.68 & 4.65 & 0.01 & NS \\
\hline Lactose yield, $\mathrm{kg} \mathrm{d}^{-1}$ & $1.34^{\mathrm{b}}$ & $1.40^{a}$ & $1.32^{\mathrm{b}}$ & 0.01 & $<0.01$ \\
\hline Total solids content, \% & 11.70 & 11.82 & 11.78 & 0.04 & NS \\
\hline Total solids yield, $\mathrm{kg} \mathrm{d}^{-1}$ & $3.35^{\mathrm{b}}$ & $3.50^{\mathrm{a}}$ & $3.33^{\mathrm{b}}$ & 0.03 & $<0.01$ \\
\hline Milk urea-N, mg dL-1 & $14.53^{c}$ & $15.76^{b}$ & $16.48^{a}$ & 0.14 & $<0.01$ \\
\hline Plasma urea-N, mg dL $\mathrm{dL}^{-1}$ & $13.88^{c}$ & $14.95^{\mathrm{b}}$ & $15.78^{a}$ & 0.22 & $<0.01$ \\
\hline Plasma glucose, $\mathrm{mg} \mathrm{dL}^{-1}$ & 60.61 & 61.53 & 62.26 & 0.69 & NS \\
\hline BCS variation & $-0.04^{b}$ & $-0.05^{b}$ & $+0.09^{a}$ & 0.03 & $<0.01$ \\
\hline
\end{tabular}

${ }^{13.5 \% \mathrm{FCM}}=0.4324\left(\mathrm{~kg}\right.$ of milk) +16.216 (kg of fat). ${ }^{2}$ Treatments: Control $=16 \% \mathrm{CP} ; \mathrm{SBCS}-17.5=17.5 \%$ CP, with extra soybean meal and cottonseed meal; U-17.5 = 17.5\% CP, with extra urea. ${ }^{3} \mathrm{SEM}=$ standard error of mean. ${ }^{4}$ Teste $\mathrm{F}$ probability.

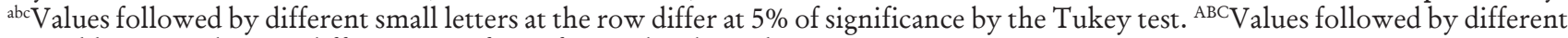
capital letters at the row differ at $15 \%$ of significance by the Tukey test.

lizable protein flow to the duodenum of dairy cows (NRC, 2001). Reduced fermentation due to RDP deficiency may decrease DMI, however, there is no conclusive report found in bibliographic references on effects of dietary CP content on DMI. Eighty two studies and 393 means were used in the NRC (2001) data set to evaluate milk and milk protein yield responses to changes in the concentration of dietary CP. In this data set there was no correlation between DMI and dietary CP content. Davidson et al. (2003) also found no effect of CP (between 16.5 and $19.4 \% \mathrm{CP}$ ) and RUP contents (between 5.94 and $7.79 \% \mathrm{DM}$ ) on DMI, which ranged from 22.9 to $24.1 \mathrm{~kg} \mathrm{~d}^{-1}$. In more recent studies with cows producing from 36.3 to $43.3 \mathrm{~kg} \mathrm{~d}^{-1}$ of milk increasing dietary CP from $16.2-17.2 \%$ up to $20 \%$ did not increase DMI in five of seven studies (Ipharraguerre and Clark, 2005b; Reynal and Broderick, 2005; Groff and Wu, 2005; Olmos Colmeneiro and Broderick, 2006a,b; Cyriac et al., 2008).

Positive effects of increasing diet CP on DMI have been reported in some studies. Reynal and Broderick (2003) observed lower DMI $\left(7.7 \%\right.$, or $\left.1.8 \mathrm{~kg} \mathrm{~d}^{-1}\right)$ in cows that received a diet containing $16 \% \mathrm{CP}$ when compared to animals fed a $19 \% \mathrm{CP}$ diet, with the extra CP provided by soybean meal. Broderick (2003) observed a crescent linear effect on DMI when soybean meal partially replaced high moisture corn in increasing amounts of $4.4 \%$ of total $\mathrm{DM}$, resulting diets with increasing $\mathrm{CP}$ contents (15.1, 16.7 and $18.4 \% \mathrm{CP})$. Dry matter intake increased 0.9 and $1.4 \mathrm{~kg} \mathrm{~d}^{-1}$ for diets containing 16.7 and $18.4 \%$, respectively, as compared to the $15.1 \%$ CP diet. A higher DMI associated with high CP content may result in increased fermentative activity, which results in a higher production of microbial protein and short-chain fatty acids (Edwards et al., 1980; Huber and Kung Jr., 1981; Imaizumi et al., 2002; Kung Jr. and Huber, 1983).

Increasing dietary CP in diets low in RDP may increase DMI (NRC, 2001). Law et al. (2009) reported increase in DMI when dietary CP $(11.4 \%)$ and RDP $(7.55 \%)$ were increased to 14.4 and $9.45 \%$ respectively. Further increases in CP and RDP to 17.3 and $11.24 \%$, respectively, did not increase DMI. Similarly, Cyriac et al. (2008) also reported an increase in DMI when dietary $\mathrm{CP}$ and RDP were increased from 13.6 and $7.6 \%$ to 15.2 and $8.8 \%$, respectively. Further increases in dietary $\mathrm{CP}$ 
Imaizumi et al.

and $\mathrm{RDP}$ to 16.8 and $10.1 \%$, respectively, did not increase DMI. Cabrita et al. (2007) reported increased DMI with increased dietary CP (13.2 to $15.2 \%)$ in high citrus pulp diet, but not for high starch diets. On the other hand, Reynal and Broderick (2005) and Kalscheur et al. (2006) did not report any increase on DMI when cows fed diets deficient in RDP according to NRC (2001) 7.7 and $6.8 \%$ of DM, respectively) were supplied with extra RDP.

Ipharraguerre and Clark (2005b) compared three dietary CP contents $(14.8,16.8$, and $18.7 \%)$ and two sources of CP (solvent-extracted soybean meal and a mixture of soybean meal and a blend of animal-marine protein supplements plus ruminally protected methionine). For early lactating cows (day 15 to 112 of lactation) fed solvent-extracted soybean meal, DMI was increased when dietary CP was increased from 16.8 to $18.7 \%$. For cows fed the mixture of soybean meal and a blend of animalmarine protein supplements plus ruminally protected methionine, DMI was increased when dietary $\mathrm{CP}$ was increased from 14.8 to $16.8 \%$. In a companion paper (Ipharraguerre et al, 2005), dietary CP content increased DMI without a positive effect on ruminal fermentation of organic matter or on the amount of microbial $\mathrm{N}$ that passed to the small intestine. Based on that, Ipharraguerre and Clark (2005b) suggested that the reduced DMI for the low CP diet was probably independent of a shortage of RDP that impaired nutrient digestibility. Ipharraguerre and Clark (2005b) speculated that, the higher dietary content of NFC, particularly starch, in the low protein diets, could result in increased supply of rumen propionate to the liver, providing a signal for hypophagia, leading to reduced DMI.

In the present study, the positive effect of extra urea on DMI was unexpected. The Control diet was adequate in RDP according to NRC (2001). Also, milk and plasma urea nitrogen concentrations $\left(14.53\right.$ and $13.88 \mathrm{mg} \mathrm{dL}^{-1}$, respectively) in the Control diet do not indicate a RDP deficiency. Lower DMI for the control diet could be due to its higher non-fiber carbohydrate (NFC) content as pointed by Ipharraguerre and Clark (2005b); however, the reduction on the NFC content $(45.6 \times 44.3 \%)$ was too small in the U-17.5 diet to support this theory. Schwab (personal communication) recommended 10.4 to $10.8 \%$ $\mathrm{RDP}$ in the diet DM to optimize rumen fermentation and microbial synthesis, when using the NRC (2001) model for high producing dairy cows. In the present study, the Control diet contained 10.2\% RDP. This value was based on ingredients RDP tabular values (NRC, 2001). There is a possibility that real diets RDP values were lower than the predicted ones. This could explain the increase in DMI when feeding more $\mathrm{CP}$ as urea in the diet.

Milk yield was greater $(p<0.01)$ for cows fed SBCS17.5 than for cows fed control or U-17.5 diets. Increases in dietary $\mathrm{CP}$ increased milk yield consistently when the control diets were 15\% CP or less (Broderick, 2003; Ipharraguerre and Clark, 2005b; Groff and Wu, 2005; Kalscheur et al., 2006; Olmos Colmeneiro and Broderick, 2006b; Wang et al., 2007; Cabrita et al., 2007;
Cyriac et al., 2008 and Law et al., 2009). Some association between increases in milk yields and in DMI were observed in six of these nine studies (Broderick, 2003; Ipharraguerre and Clark, 2005b; Groff and Wu, 2005; Cabrita et al., 2007; and Cyriac et al., 2008 and Law et al., 2009). Broderick (2003) increased dietary CP by adding soybean meal at the expense of high moisture corn to obtain dietary CP contents of $15.1,16.7$ and $18.4 \%$. DMI was increased linearly with incremental CP increase, however, milk and $3.5 \%$ fat corrected milk (FCM) productions were increased only with the first incremental CP increase. Ipharraguerre and Clark (2005b) increased dietary CP by adding soybean meal to obtain dietary CP contents of $14.8,16.6$ and 18.5 or a blend of animal-marine protein supplement plus rumen protected methionine to obtain dietary $\mathrm{CP}$ contents of $14.9,17.0$ or $19 \%$. Milk production was increased only with the first incremental CP increase. Only for the blend of animal-marine protein supplement plus rumen protected methionine this increase in milk yield was associated to higher DMI.

Groff and $\mathrm{Wu}$ (2005) conducted 4 trials where the control diets contained 16.6 (trial 1), 14.5 (trial 2), 15.7 (trial 3) and 16.2\% (trial 4) dietary CP. Increasing CP up to $20 \%$ increased milk yield only in trial 2 and it was associated to increased DMI. In the other 3 trials dietary $\mathrm{CP}$ of the control diets were enough to maximize DMI and milk yields. Cabrita et al. (2007) reported increased DMI and milk yield when dietary CP was increased from 13.2 to $15.2 \%$ in diets high in citrus pulp and low in starch. For diets high in starch both DMI and milk yield were not affected by increased dietary CP. Cyriac et al. (2008) reported linear increase in DMI and milk yield when dietary CP was increased from 13.6 to $16.8 \%$. In the study of Law et al. (2009), both milk yield and DMI increased when dietary CP was from 11.4 to $14.4 \%$. However, when dietary CP was increased to $17.3 \%$, milk yield was still increased but DMI was not.

In most of the reviewed studies, feeding diets with more than $16 \%$ CP did not increase milk yield. Davidson et al. (2003) observed no effects of increasing dietary CP (from 16.5 to $19.4 \% \mathrm{CP}$ ) and RUP (from 5.94 to $7.76 \%$ DM) on milk (between 33 and $35.3 \mathrm{~kg} \mathrm{~d}^{-1}$ ) and $4 \%$ FCM production (between 29.2 and $31.8 \mathrm{~kg} \mathrm{~d}^{-1}$ ). Olmos Colmeneiro and Broderick (2006a,b) and Cyriac et al. (2008) reported no increases in milk yields when more than $16.6 \%$ dietary CP was fed to cows producing 36.3 to $42.1 \mathrm{~kg} \mathrm{~d}^{-1}$ of milk. For early lactating cows fed soybean meal and producing up to $43.3 \mathrm{~kg} \mathrm{~d}^{-1}$ of milk, Ipharraguerre and Clark (2005b) reported no increase in milk yield when dietary $\mathrm{CP}$ was increased from 16.6 to 18.5\%. Groff and Wu (2005) did not report any increase in milk yield in 3 of 4 studies with dietary CP higher than $16.2 \%$ for cows producing 31.5 to $39.3 \mathrm{~kg} \mathrm{~d}^{-1}$. of milk. Reynal and Broderick (2005) reported no increase in milk yield with dietary CP greater than $17.2 \%$ for early lactating cows producing around $42 \mathrm{~kg} \mathrm{~d}^{-1}$ of milk. However, Reynal and Broderick (2003) observed that in com- 
parison to cows fed a diet containing $15.8 \% \mathrm{CP}$ with urea as the sole supplemental CP source, increasing the CP content to $19-20 \%$ by the addition of natural protein sources resulted in increases in milk production from 3.6 to $5.7 \mathrm{~kg} \mathrm{cow}^{-1} \mathrm{~d}^{-1}$.

Mid lactating cows, producing around $28-30 \mathrm{~kg} \mathrm{~d}^{-1}$ of milk, when fed diets containing 16\% CP and formulated to be adequate in RDP and RUP (NRC 2001) were not expected to respond to extra protein supplementation. However, in the present study, increasing dietary CP from 15.9 to $17.5 \%$ with extra blend of soybean meal and cottonseed meal increased milk and milk protein yields. A greater metabolizable energy and protein flows to the small intestine of cows fed the SBCS-17.5 diet is a plausible hypothesis to explain the increase in observed milk and milk protein yields. The hypothesis that additional urea to the control diet increased the flow of metabolizable energy but not of protein is supported by the positive body condition score (BCS) variation of cows fed the U-17.5 diet. Apparently cows fed the U-17.5 diet were not able to use the absorbed extra energy for milk synthesis, due to a deficiency in metabolizable protein, and so, stored this energy as fat tissue.

Milk fat contents and yields were not affected by dietary CP content $(p>0.05)$. In most reviewed studies (Davidson et al., 2003; Reynal and Broderick 2003, and 2005; Ipharraguerre and Clark, 2005b; Groff and Wu, 2005; Olmos Colmeneiro and Broderick, 2006a; Cabrita et al., 2007 and Cyriac et al., 2008) milk fat content was not affected by dietary CP content. In this study milk fat contents were lower than expected. According to NRC (2001) dietary total NDF and forage NDF were adequate, however dietary contents of NFC were higher (43.7 to $45.6 \%$ ) than recommended, and may have affected milk fat contents.

Milk protein content was lower $(p<0.01)$ for U-17.5 treatment than for the other two treatments and milk protein yield was higher $(p<0.01)$ for the SBCS-17.5 than for the control and U-17.5 treatments. Positive effect of the SBCS-17.5 diet on milk protein yield was due increased milk yield in this treatment. Milk protein content was not affected by dietary CP content in most of the recent studies (Davidson et al., 2003; Reynal and Broderick, 2003; Ipharraguerre and Clark, 2005b; Goff and Wu, 2005; Olmos Colmeneiro and Broderick, 2006a,b; Kalscheur et al., 2006; Cabrita et al., 2007; Wang et al., 2007; Cyriac et al., 2008; and Law et al., 2009) .

Plasma and milk urea-N reflect the CP content in the diets, CP degradability and quality. MUN concentrations tend to equilibrate with plasma urea nitrogen (PUN) concentrations. Concentrations of MUN and PUN were lower $(p<0.01)$ in animals fed control ration, intermediate in those fed SBCS-17.5 and highest in those fed U-17.5, which is consistent with RDP availability and CP content (Tables 1 and 2). MUN was increased as dietary CP increased. Similar increases in MUN have been observed in other studies (Baker et al., 1995; Colin-Schoellen et al., 2000; Sutton et al., 1996).
Even though Reynal and Broderick (2003) did not measure MUN, increases in PUN (9\%) and rumen ammonia $(40.3 \%)$ concentrations were observed in animals fed higher CP content diets (16\% vs $19 \% \mathrm{CP}$, by the addition of soybean meal).

According to Broderick et al. (1993), blood urea nitrogen (BUN) concentrations lower than $4 \mathrm{mM}$ or below $11 \mathrm{mg} \mathrm{dL} \mathrm{L}^{-1}$ of $\mathrm{N}$ indicate a dietary RDP limitation, which was not observed in the present study, as indicated by the average plasma urea nitrogen (PUN) values between 13.88 and $15.78 \mathrm{mg} \mathrm{dL}^{-1}$. There were no treatment effects on plasma glucose concentrations $(p>$ 0.05), which were in the normal physiological range.

Body condition score variation was positive for cows fed the U-17.5 diets and negative for cows fed the other 2 diets $(p<0.01)$. It is possible that cows fed the U-17.5 diets had higher energy intake because of the higher DMI. However, lack of enough metabolizable protein may have limited milk and milk protein synthesis compared to SBCS-17.5, resulting in fat deposition.

Although current diet formulation systems such as AFRC (1992), CNCPS (Sniffen et al., 1992) and NRC (2001) have incorporated complex calculations to estimate rumen protein synthesis and degradation, the lack of information about the kinetics of rumen protein degradation, as well as adequate methodologies for data generation, may lead to unsuccessful practical application of diet formulation. It is common to adopt a feeding routine to supply extra amounts of protein to avoid possible amino acid deficiencies to the small intestine in a way that could compromise lactational performance (Reynal and Broderick, 2003).

Even though the control and U-17.5 treatments supplied sufficient amounts of MP and that treatment SBCS17.5 supplied MP in excess according to the NRC (2001), control and U-17.5 may have supplied insufficient amounts of MP or amino acids for absorption in the small intestine, resulting in lower production of milk and milk protein than treatment SBCS-17.5.

\section{Acknowledgements}

To FAPESP for the financial support for the study and the scholarship for the first author during the graduate program.

\section{References}

Agricultural And Food Research Council [AFRC]. Technical Committee on Responses to Nutrients. 1992. Nutritive requirements of ruminant animals: protein; report n.9. Nutrition Abstracts Review. Series B 62: 787-835.

Association of Official Analytic Chemists International. [AOAC]. 1990. Official Methods of Analyses. 15ed. AOAC, Arlington, VA, USA. 473p.

Baker, L.D.; Ferguson, J.D.; Chalupa, W. 1995.Responses in urea and true protein of milk to different protein feeding schemes for dairy cows. Journal of Dairy Science.78: 2424-2434.

Broderick, G.A. 2003. Effects of varying dietary protein and energy levels on the production of lactating dairy cows. Journal of Dairy Science 86: 1370-1381. 
Broderick, G.A.; Craig, W.M.; Ricker, D.B. 1993. Urea versus true protein as supplement for lactating dairy cows fed grain plus mixtures of alfafa and corn silages. Journal of Dairy Science 76: 2266-2274.

Cabrita, A.R.J.; Bessa, R.J.B.; Alves, S.P.; Dewhurst, R.J.; Fonseca, A.J.M. 2007. Effects of dietary protein and starch on intake, milk production, and milk fatty acid profiles of dairy cows fed corn silage-based diets. Journal of Dairy Science 90: 1429-1439.

Canfield, R.W.; Sniffen, C.J.; Butler, W.R. 1990. Effects of excess degradable protein on postpartum reproduction and energy balance in dairy cattle. Journal of Dairy Science 73: 2342-2349.

Colin-Schoellen, O.; Jurjanz, S.; Laurent, F. 2000. Metabolizable protein supply (PDIE) and restricted level of ruminally degradable nitrogen (PDIN) in total mixed rations: effect on milk production and composition and on nitrogen utilization by dairy cows. Livestock Production Science 67: 41-53.

Cyriac, J.; Rius, A.G.; McGilliard, M.L.; Pearson, R.E.;. Bequette, B.J.; Hanigan, M. D. 2008. Lactation performance of midlactation dairy cows fed ruminally degradable protein at concentrations lower than National Research Council recommendations. Journal of Dairy Science 91: 4704-4713.

Davidson, S.; Hopkins, B.A.; Diaz, D.E.; Bolt, S.M.; Brownie, C.; Fellner, V.; Whitlow, L.W. 2003. Effects of amount and degradability of dietary protein on lactation, nitrogen utilization, and excretion in early lactation Holstein cows. Journal of Dairy Science 86: 1681-1689.

Edwards, J.S.; Bartley, E.E.; Dayton, A.D. 1980. Effects of dietaryprotein concentration on lactating cows. Journal of Dairy Science 63: 243-248.

Goering, H.K.; Van Soest, P.J. 1970. Forage Fiber Analyses (Apparatus, Reagents, Procedures, And Some Applications). 1970. USDA-ARS, Washington, D.C. USA. (Agricriculture Handbook, 379).

Groff, E.B; Wu, Z. 2005. milk production and nitrogen excretion of dairy cows fed different amounts of protein and varying proportions of alfalfa and corn silage. Journal of Dairy Science 88: 3619-3632.

Hof, G.; Vervoorn, M.D.; Lenaers, P.J.; Tamminga, S. 1997. Milk urea nitrogen as a tool to monitor the protein nutrition of dairy cows. Journal of Dairy Science 80: 3333-3340.

Huber, J.T.; Kung Jr.,L. 1981. Protein and non-protein nitrogen utilization by dairy cattle. Journal of Dairy Science 64: 11701195.

Imaizumi, H.; Santos, F.A.P.; Pires, A.V.; Nussio, C.M.B.; Barnabe, E.C.; Juchen, S.O. 2002. Avaliação de diferentes fontes e teores de proteína na dieta sobre o desempenho, fermentação ruminal e parâmetros sangüíneos de vacas da raça Holandesa em final de lactação. Acta Scientiarum 24: 1031-1037.

Ipharraguerre, I.R.; Clark, J.H. 2005a. Impacts of the source and amount of crude protein on the intestinal supply of nitrogen fractions and performance of dairy cows. Journal of Dairy Science 88: E22-37E.

Ipharraguerre, I.R.; CLARK, J.H. 2005b. Varying protein and starch in the diet of dairy cows. II. Effects on performance and nitrogen utilization for milk production. Journal of Dairy Science 88: 2556-2570.

Ipharraguerre, I.R.; Clark, J.H.; Freeman, D.E. 2005. Varying Protein and starch in the diet of dairy cows. I. Effects on ruminal fermentation and intestinal supply of nutrients. Journal of Dairy Science 88: 2537-2555.

Kalscheur, K.F.; Baldwin, R.L.; Glenn, B.P.; Kohn, R.A. 2006. Milk production of dairy cows fed differing concentrations of rumen-degraded protein. Journal of Dairy Science 89: 249-259.

Kung Jr., L.; Huber, J.T. 1983. Performance of high producing cows in early lactation fed protein of varying amounts, sources and degradability. Journal of Dairy Science 66: 227-234.
Law, R.A.; Young, F.J. ; Patterson, D.C. ; Kilpatrick, D.J.; Wylie, A.R.G.; Mayne, C.S. 2009. Effect of dietary protein content on animal production and blood metabolites of dairy cows during lactation. Journal of Dairy Science 92: 1001-1012.

Moorby, J.M.; Dewhurst, R.J.; Thomas, C.; Marsden, S. 1996. The influence of dietary energy source and dietary protein level on milk protein concentration from dairy cows. Animal Science 63: $1-10$.

National Research Council [NRC]. 1985. Ruminant nitrogen usage. Washington: National Academy Press, Washington, D.C., USA. 138p.

National Research Council [NRC]. 1989. Nutrient requirements of dairy cattle. 6.ed. Washington: National Academy Press, Washington, D.C., USA. 158p.

National Research Council [NRC]. 2001. Nutrient Requirements of Dairy Cattle. 7ed. National Academy Press, Washington, D.C., USA. 408 p.

Olmos Colmenero, J.J.; Broderick, G.A. 2006a. Broderick effect of dietary crude protein concentration on milk production and nitrogen utilization in lactating dairy cows. Journal of Dairy Science 89: 1704-1712.

Olmos Colmenero, J.J.; Broderick, G.A. 2006b Effect of dietary crude protein concentration on ruminal nitrogen metabolism in lactating dairy cows. Journal of Dairy Science 89: 1694-1703.

Rajala-Schultz, P.J.; Saville, W.J.A.; Frazer, G.S.; Wittum, T.E. 2001. Association between milk urea nitrogen and fertility in Ohio dairy cows. Journal of Dairy Science 84: 482-489.

Reynal, S.M.; Broderick, G.A. Effect of dietary level of rumendegraded protein on production and nitrogen metabolism in lactating dairy cows. 2005. Journal of Dairy Science 88: 40454064.

Reynal, S.M.; Broderick, G.A. 2003. Effects of feeding dairy cows protein supplements of varying ruminal degradability. Journal of Dairy Science 86: 835-843.

SAS Institute. 1991. SAS User's Guide: Statistics; Version 5. SAS Institute, Cary, NC, USA. 1028p.

Silva, D.J. Análise de Alimentos: Métodos Químicos e Bromatológicos. 1990. 2ed. Imprensa Universitária, Viçosa, MG, Brazil. 165p.

Sniffen, C.J.; O’Connor, J.D.; Van Soest, P.J.; Fox, D.G.; Russell, J.B. 1992. A net carbohydrate and protein system for evaluating cattle diets. II. Carbohydrate and protein availability. Journal of Animal Science 70: 3562-3577.

Sutton, J.D.; Aston, K.; Beever, D.E.; Dhanoa, M.S. 1996. Milk production from grass silage diets: effects of high-protein concentrates for lactating heifers and cows on intake, milk production and milk nitrogen fractions. Animal Science 62: 207-215.

Tamminga, S. Nutrition management of dairy cows as a contribution to pollution control. 1992. Journal of Dairy Science 75: 345-357.

Van Soest, P.J.; Robertson, J.B.; Lewis, B.A. Methods for dietary fiber, neutral detergent fiber, and nonstarch polysaccharides in relation to animal nutrition. 1991. Journal of Dairy Science 74: 3583-3596.

Wang, C.; Liu, J.X.; Yuan, Z.P.; Wu, Y.M.; Zhai, S.W.; Ye, H.W. 2007. Effect of level of metabolizable protein on milk production and nitrogen utilization in lactating dairy cows. Journal of Dairy Science 90: 2960-2965.

Wildman, E.E.; Jones, G.M.; Wagner, P.E.; Boman, R.L.; Troutt Jr, R.; Lesch, T.N. 1982. A dairy condition scoring system and its relationship to selected production characteristics. Journal of Dairy Science 65: 495-501.

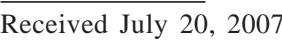

Accepted September 16, 2009 